\title{
Model Enterprise Resouce Planning Sistem Informasi Akademik Menggunakan Togaf Pada Universitas Peradaban
}

\author{
Mukrodin $^{1 *}$, Oman Somantri ${ }^{2}$ \\ ${ }^{1}$ Jurusan Sistem Informasi, Fakultas Sains dan Teknologi, Universitas Peradaban \\ ${ }^{2}$ Program Studi Teknik Informatika, Politeknik Harapan Bersama Tegal \\ ${ }^{1}$ Jl. Raya Pagojengan KM 03 Paguyangan - Brebes, Indonesia \\ ${ }^{2}$ Jln. Mataram No.09 Pesurungan Lor Tegal, Indonesia \\ email: ${ }^{1}$ mukrodins@gmail.com, ${ }^{2}$ oman_mantri@yahoo.com
}

Copyright @2019, Politeknik Harapan Bersama, Tegal

\begin{abstract}
The progress of information systems in the education sector is so developed that it requires to carry out academic activities online. To implement and facilitate the acceleration of higher education, the University of Peradaban as the organizer of higher education in the Bumiayu Subdistrict of Brebes Regency, currently does not have an information system that is integrated with academic information systems (SIA), therefore an information system needs analysis. The Togaf Framework is a framework that can see problems and the development of a comprehensive information system. The goal is to build a model Eneterprise Resource Planing academic information system to support the strategy of developing academic information systems as needed at the University of Peradaban. The type of research used is qualitative research that is explorative, which is to look deeply into the needs of users in applying academic information systems at the University of Peradaban. Analysis of the planner's scope, SIA is designed to manage Lecturer data, Student data, class schedules, Card Management Study Plan, Study Card processing and management of value transcripts and alumni data management. System development consists of three parts, namely a system that can be used by academic administrative staff, lecturers and can be used by students. SIA is designed to provide speed and convenience in managing data and academic development for the competitiveness of universities.
\end{abstract}

Abstrak - Kemajuan sistem informasi bidang pendidikan begitu berkembang mewajibkan untuk melakukan aktivitas akademik secara online. Untuk melaksanakan dan memfasilitasi percepatan perguruan tinggi, Universitas Peradaban sebagai penyelenggara pendidikan tinggi di Kecamtan Bumiayu Kabupaten Brebes, saat ini belum memiliki sistem informasi yang terintegrasi dengan sistem informasi akademik (SIA), untuk itu perlu dilakukan analisis kebutuhan sistem informasi. Framework Togaf merupakan kerangka kerja yang dapat melihat permasalahan dan pengembangan sistem informasi yanga menyeluruh. Tujuannya adalah membangun model Eneterprise Resource Planing sistem informasi akademik untuk mendukung strategi pengembangan sistem informasi akademik sesuai kebutuhan di Universitas Peradaban. Jenis penelitian yang digunakan adalah penelitian kualitatif bersifat eksploratif,

*) penulis korespondensi: Mukrodin

Email: mukrodins@gmail.com yaitu untuk mencari secara mendalam kebutuhan pengguna dalam menerapakan sistem informasi akademik di Universitas Peradaban. Analisis ruang lingkup perencana, SIA dirancang untuk memanajemen data Dosen, data Mahasiswa, jadwal kuliah, pengelolaan Kartu Rencana Studi, pengolahan Kartu Hasil Studi dan pengelolaan transkrip nilai serta pengelolaan data alumni. Pengembangan sistem terdiri dari tiga bagian yaitu sistem yang dapat digunakan oleh staf administrasi akademik, dosen dan dapat digunakan oleh mahasiswa. SIA yang dirancang memberikan kecepatan dan kemudahan dalam mengelola data serta pengembangan akademik untuk daya saing perguruan tinggi.

Kata Kunci - Eneterprise Resource Planing, Sistem Informasi Akademik (SIA), Framework Togaf

\section{PENDAHULUAN}

Pertumbuh dan berkembangnya information technology dan information system yang begitu cepat dan pesat menuntut semua layanan harus lebih cepat dan tepat sesuai dengan perkembangan teknologi terutama di era industri 4.0, Keduanya merupakan hal yang tidak terpisahkan baik untuk perusahaan atau organisasi besar, menengah atau organisasi kecil. Perencanaan sistem yang mengacu pada penerapan teknologi informasi dan sistem informasi merupakan dasar bagi organisasi untuk berkembang ke arah yang lebih baik dalam hal efektifitas dan efisiensi kinerja organisasi. Dengan menerapkan teknologi informasi diharapkan organisasi dapat meningkatkan kemampuan daya saing.

Pemanfaatan database yang yang terintegrasi dalam sebuah perusahaan menjadikan sebuah organisasi untuk menjadi sebuah yang populer dan dapat menjadi sebuah rujukan oraganisai-oranisasi yang lain. Kemampuan untuk mengelola database dengan baik adalah suatu hal yang sangat penting sekali dalam membangun sebuah bisnis proses suatu oraganisasi yang baik, karena di era industri 4.0 di utuhkan akses data yang begitu cepat dan tepat. Hal ini dibutuhkan sebuah perencanaan yang matang.

Ketepatan dalam menerapkan teknologi informasi dan komunikasi serta sistem informasi dalam sebuah oraganisasi menenuntu sebuah perencanaan yang matang untuk 
mengurangi resiko yang akan terjadi dalam penerapannya sistem informasi akademik yang ada di Universitas Peradaban. Dalam perencanaan dan pengemebangan teknologi infromasi dan sistem informasi akademik di Universitas Peradaban yang handal maka diperlukan sebuah Enterprise Resource Planing yang baik. Arsitektur enterprise adalah sebuah pendekatan logis, komprehensif, dan holistik untuk merancang dan mengimplementasikan sistem dan komponen sistem secara bersamaan (Perizaue, 2002).

Dalam penelitian ini akan digunakan metode Framework Togaf dengan menggunakan perancangan arsitektur enterprise, sehingga didapatkan gambaran yang jelas bagaimana melakukan perancangan arsitektur enterprise, untuk mendapatkan sebuah arsitektur enterprise yang baik dan bisa digunakan organisasi untuk mencapai tujuan strategisnya. Luaran yang dapat dicapai dari rancangan arsitektur enterprise ini adalah menghasilkan model dan blue print untuk mengembangkan sistem informasi akademik yang terintegrasi untuk mendukung kebutuhan organisasi pengembangan dan tujuan integrasi yang sebenarnya. Adapun implementasinya adalah pada Universitas Peradaban yang berlokasi di Jl. Raya Pagojengan Km 03 Kecamatan Paguyangan Kabupaten Brebes.

\section{PENELITIAN YANG TERKAIT}

Penelitian ini dilakukan tidak lepas dari hasil penelitianpenelitian terdahulu atau penelitian yang pernah dilakukan sebagai bahan perbandingan dan sebagai kajian. Adapun hasil penelitian yang dijadikan perbandingan tidak lepas dengan topik penelitian enterprise architecture mengenai pengembangan sistem informasi akademk dengan menggunakan framework Togaf, di anataranya sebagai berikut:

Ridwan Setiawan (2015), dalam jurnalnnya merancang arsitektur enterprise pada perguruan tinggi swasta. Penelitian ini memakai Metodologi The Open group Architecture Framework Architecture Develoment Methode (TOGAF ADM) dengan pendekatan object oriented. Penelitian ini menghasilkan sebuah rancangan sistem informasi akademik di Universitas Perdaban untuk meningkatkan kinerja disetiap bagian organisasi agar menghasilkan informasi baik dan benar serta tepat sasaran. Hasil penelitian ini berupa blueprint.

Yeni Kustiahningsih (2013), jurnal ini merencanakan sebuah arsitektur Enterprsise pada sebuah rumah sakit Dr. Soegiri Lamongan, dengan menggunakan framework TOGAF untuk meningkatkan kulaitas pelayanan. Hasil penelitian ini berupa blueprint.

C. Rachman Mardiansyah (2012), penelitian ini menganalisis dan mengembangkan enterprise arsitektur sistem pada pengadilan agama di bandung dengan menggunakan framework TOGAF, luaran penelitian ini adalah menghasilkan sebuah arsitekktur enterprise pada sebuah oraganisasi untuk mencapai tujuan strategis.

Ahmad Suryadi (2015), jurnal ini membuat startegi perencanaan dan penerapan teknologi informasi pada sebuah Sekolah Menengah Kejuruan dengan menggunakan framework TOGAF, luaran penelitian ini membuat model, mengembangkan dan penerapan artsitektur enterprise.
Roni Yunis (2009), Jurnal ini merancang model enterprise architecture sebuah bisnis dan teknologi informasi dalam sebuah organisasi dengan menggunakan framework TOGAF, luaran dari penelitian ini adalah menghasilkan sebuah arsitektur enterprise yang dapat di jadikan organisasi untuk mencapai tujuan startegis.

\section{ENTERPRISE RESOUCE PLANING (ERP) \& FRAMEWORK TOGAF}

\section{A. Enterprise Resouce Planing}

Menurut Umble, Haft dan Michael (2002), yang menentukan sebuah keberhasilan dalam menerapkan diperusahaan seupaya lebih efektif dan efisien adalah dengan menerapkan information system Enterprise Resouce Planing (ERP).

Penerapan eneterprise resource planning adalah salah satu indikator penentuk keberhasilan sebuah organisasi yang sistematis dan terarah, serta dapat membantu Universitas Peradaban dalam meningkatkan teknologi infromasi dan sistem informasi khususnya para pengguna sistem informasi akademik di. Enterprise resource planning mamapu menerapkan startegi organisai menuju keberhasilan penerapakan teknologi informasi dan sistem infromasi akademik yang baik serta mampu menerapkan perubahan manajemen, kinerja pengguna, keakuratan pemilihan database, serta mampu melakukan pelatihan dan pendidikan yang terbaik serta berfokus pada kinerja yang efektif dan efisien. Menurut Zhang dan Lee (2003), ada bebrapa yang menentukan keberhasilan dalam menerapkan Enterprise resource planning dianataranya adalah sebagai berikut: dukungan manajemen puncak, business process reengineering, manajemen projek yang efektif, komitmen pimpinan, pendidikan dan pelatihan ketepatan pemilihan software dan hardware, user involvement, keakuratan data, dukungan vendor dan kultur organisasi.

Penelitian oleh (Zhang, Lee, Benerjee, 2001), mengatakan bahwa untuk memperoleh keberhasilan dalam menerapkan enterprise resource planning harus ada dukungan top level manajemen memiliki dua komponenen antara lain: jiwa kepemimpinan dan penyediaan sumber daya perusahaan yang diperlukan.

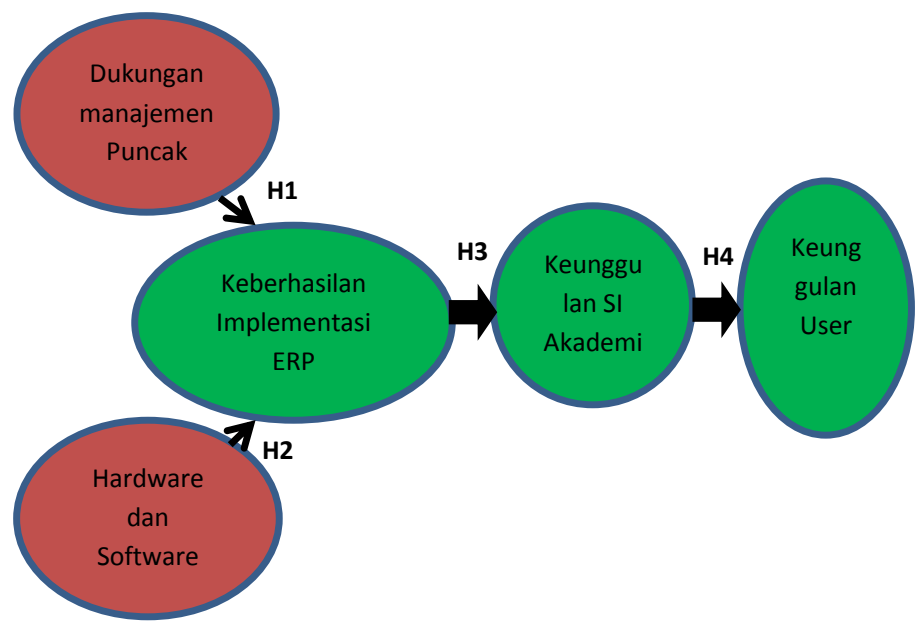

Gbr 1. Kerangka pemikiran 


\section{B. The Open Group Architecture Framework (TOGAF)}

TOGAF dikembangkan oleh The Open Group's pada tahun 1995. Awalnya TOGAF dipergunakan oleh departemen pertahanan Amerika Serikat namun pada perkembangannya TOGAF kenyataanya juga digunakan diberbagai bidang perusahaan seperti: perbankan, industri manufaktur dan juga pendidikan. TOGAF digunakan untuk mengembangkan arsitektur enterprise, juga terdapat metode dan tools yang lengkapa dalam penerapannya, hal tersebut dapat yang dapat membedakan dengan framework arsitektur enterprise lain seperti: framework zachman, Federal enterprise architecture (FEA, Gartner dll.

Keunggulan dari framework TOGAF ini bila di bandingkan dengan framework yang lainya adalah karena lebih bersifat fleksibel dan bersifat open source. Framework TOGAF juga dapat memberikan sebuah metode yang lebih lengkapa dan dan terstruktur dalam sebuah oraganisasi serta dalam menerapkan arsitektur enterprise teknologi informasi dan sistem informasi yang disebut dengan Architecture Development Method (ADM) [7]. ADM merupakan sebuah metode yang umum dan mudah di implementasikan yang berisi beberapaa kegiatan untuk melakukan pemodelan dan pengembangan arsitektur enterprise.

TOGAF ADM merupakan sebuah metode yang mudah dan mampu mengikuti perubahan organisasi serta mampu mengidentifikasi berbagai macam teknik model yang ada di sebuah oraganisasi guna merencanakan sebuah arsitektur enterprise, karena metode ini bisa disesuaikan dengan perubahan dan kebutuhan selama perancangan dilakukan. TOGAF ADM mamapu menerapkan visi dan perinsip yang terukur dan mampu untuk melakukan pengembangan kearah masa depan terutama di era 4.0 sekarang ini, konsep tersebut di jadikan sebuah patokan dan ukuran keberhasilan sebuah pengembangan arsitektur enterprise dalam sebuah oraganisasi disetiap bagian, bagianbagian tersebut dapat dijelaskan sebagai berikut:

- Bagian Enterprise: Penerapan arsitektur enterprise yang dikembangkan diharapkan mampu memberikan dukungan kepada seluruh bagian-bagian dalam sebuah organisasi termasuk pada unit-unit yang ada dalam sebuah organisasiyang di harapkan.

- Bagian Teknologi Informasi: Mengarahkan konsistensi penrapan teknologi informasi pada seluruh bagian organisasi, termasuk unit- unit organisasi yang akan diterapkan.

- Bagian Arsitektur: Merancang arsitektur sistem berdasarkan kebutuhan proses sistem informasi akademik dan bagaimana menerapkannya.

\section{METODE PENELITIAN}

Metodologi adalah cara teratur, terstruktur dan sistematis yang digunakan untuk melaksanakan suatu pekerjaan atau kegiatan agar tercapai sesuai dengan yang diinginkan dan diharapkan dalam penelitian; cara kerja yang terencana dan terprogram dengan baik untuk memudahkan pelaksanaan suatu kegiatan guna mencapai tujuan yang ditentukan. Metode yang digunakan dalam penelitian ini pada Gbr.2.

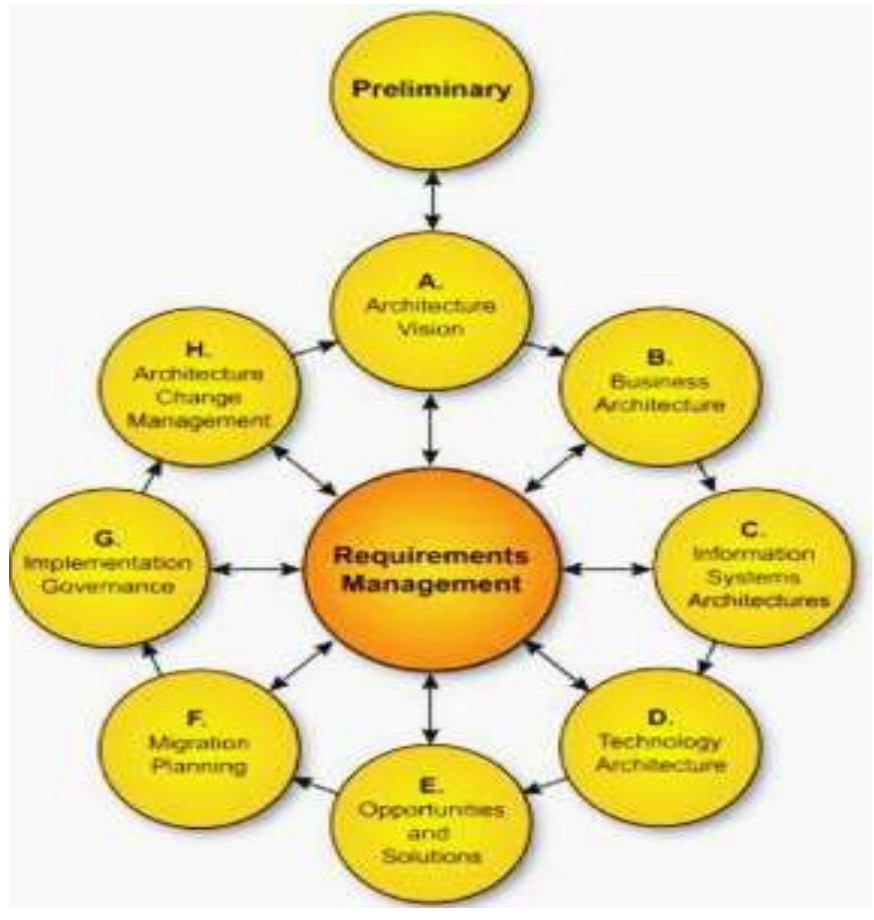

Gbr. 2 Metodologi Penelitian

1) Preliminari: Pada tahapan ini melakukan sebuah proses bisnis yang terencana dan sistematis yang berkaitan dengan sistem informasi akademik pada Universitas Peradaban dan memetakannya dengan menggunakan value chain.

2) Vision Architecture: Membangun persepsi yang sama pentingnya arsitektur enterprise untuk mencapai suatu keberhasilan sebuah organisasi yang telah dirumuskan dan direncanakan dalam bentuk strategi atau cara serta menentapkan komponen arsitektur yang akan di terapkan. Tahapan ini membahas mengenai visi dan misi dari perancangan enterprise arsitektur yang dilakukan untuk mendukung aktifitas organisasi sesuai dengan visi dan misi dari perguruan tinggi.

3) Business Architecture: Tahapan ini melakukan analisis proses bisnis dalam oraganisasi yang akan di terapakan pada perguruan tinggi sesgingga sesuai dengan perencanaan yang di lakukan.

4) Information System Architecture: Pada tahapan ini adalah melakukan menganalisis model arsitektur yang akan dirancang dan digunakan sesuai dengan apa yang diharapkan, antara lain model arsitektur data dan model sistem informasi beserta dengan proses penerapan dan implementasinya. Pada penerapannya perencanaan penyususnan tidak harus terpaku pada arsitektur sistem informasi akan tetapi bisa di lakukan pemodelannya. Itu bisa dilihat pada saat perencanaan penyusunan.

5) Sollution and Opportunities: Pada tahapan ini adalah melakukan evaluasi, penerapan sistem informasi, dan mendefinisikan strategi implementasi serta melakukan penerapan.

6) Migration Planning: Tahapan ini melakukan urutanurutan penerapan sistem infromasi yang didasarkan kepada skala prioritas. 


\section{PEMBAHASAN DAN HASIL}

\section{A. Preliminary}

Struktur oraganisasi dalam sebuah pertugurana tinggi dapat menyusun kegiatan yang ada di oraganisasi tersebut sesuai dengan bagiannya. Struktur organisasi dapat menentukan pola pemodelan bisnis kedepan dengan gambaran yang jelas. Universitas Peradaban merupakan perguruan tinggi dengan proses bisnis selalu mengedepankan serta melaksanakan tri dharma perguruan tingi, pengajaran dan pengabdian bagi masyarakat sesuai dengan amanat undang-undang dan peraturan peraturan kementrian ristek dan perguruan tinggi.

\section{B. Visi Architecture}

Pemodelan enterprise dapat menerapaka visi sebagai berikut:

- Membangun enterprise architecture sesuai dengan kebutuhan pengguna serta kebutuhan bisnis di Universitas Peradaban, sesuai dengan grand desain pengembangan Universitas dimasa yang akan datang dengan membuat model arsitektur yang diharapkan sehingga dapat meningkatkan kinerja dan pelayanan befektif dan efisien yang ada di Universitas Peradaban mulai dari pelayanan dosen, mahasiswa, kariyawan dan staf serta menumbukan optimism pada tingkat pimpinan dalam mengambil keputusan yang startegis;

- Membangun perencanaan sistem informasi akademik yang terintegrasi yang diharapkan mamapu mengintegrasikan sistem informasi yang sudah ada maupun yang belum sehingga nantinya dapat melengkapai sistem yang akan datang menjadi sistem yang terintegrasi disemua unit-unit atau bagianbagian;

- Sistem informasi akademik yang dibangun menghasilkan model sistem enterprise dapat menyediakan informasi dengan cepat, tepat dan akurat serta sistematis;

- Secara umum pembangunan sistem informasi akademik ini berbasis website, sehingga memudahkan semua pengguna bisa mengakses dimana saja kapan saja tanpa mengenal batas ruang dan waktu (fleksibility) yang tidak terbatas pada jenis platform operating system dan jenis hardware apapun;

- Pengembangan Sistem informasi akademik dapat menghemat penggunaan kerta sehingga meminimalkan pembelian biaya alat tulis dan kertas karena semua berbasis online bisa di cetak atau berupa file.

\section{Architecture Bsinis}

Pemodelan proses bisnis merupakan suatu langkah awal yang sangat penting dan mendesak dalam mengembangkan sistem informasi enterprise yang terintegrasi sehingga bernilai bagi seluruh komponen yang ada dalam organisasi. Dalam pengembangan arsitektur enterprise sistem informasi dilakukan analisis proses bisnis dan pendefinissian sub proses serta aktifitas yang detail.

\section{1) Penerimaan Mahasiswa Baru (PMB)}

Pada pada tahapan ini adalah proses pengelolaan penerimaan mahasiswa baru, perencanaan penerimaan mahasiswa baru, Promosi Penerimaan mahasiswa baru, Ujian masuk mahasiswa baru, serta proses daftar ulang atau registrasi mahasiswa baru. Hasil pengelompokan aktifitasaktifitas dari proses penerimaan mahasiswa baru, dapat dilihat pada tabel 1 .

TABEL I

ProseS PENGElolaAn PENERIMAan MAHAsiswa BarU

\begin{tabular}{|c|c|c|}
\hline No Proses & $\begin{array}{c}\text { Nama Sub } \\
\text { Proses }\end{array}$ & Aktivitas Detail \\
\hline I & $\begin{array}{l}\text { Tahap } \\
\text { Awal dan } \\
\text { Promosi } \\
\text { PMB }\end{array}$ & $\begin{array}{l}\text { Penyusunan Panitia } \text { PMB } \\
\text { Penyusunan Anggaran PMB } \\
\text { Time Schedule PMB Riset } \\
\text { Pasar Strategi Promos } \\
\text { Pengawasan dan Evaluasi } \\
\text { Strategi Promosi Laporan } \\
\text { Promosi }\end{array}$ \\
\hline II & Ujian Masuk & 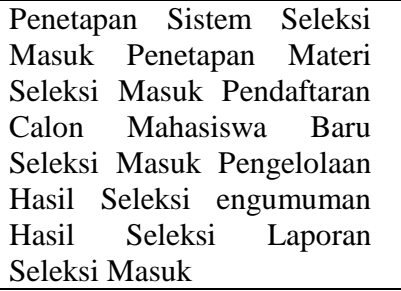 \\
\hline III & $\begin{array}{l}\text { Daftar } \\
\text { Ulang } \\
\text { Mahasiswa } \\
\text { Baru }\end{array}$ & $\begin{array}{l}\text { Pendataan Registrasi } \\
\text { Mahasiswa Penentuan nomor } \\
\text { induk mahasiswa Pencetakan } \\
\text { Kartu Tanda Mahasiswa } \\
\text { Pelaksanaan Masa Prabakti } \\
\text { Mahasiswa (MAPRAM) } \\
\text { Pelaporan Penerimaan } \\
\text { Mahasiswa Baru }\end{array}$ \\
\hline
\end{tabular}

\section{2) Bagian Administrasi Akademik (BAAK)}

Pada Proses pengelolaan Penyelenggaraan Pendidikan merupakan hal yang paling pokok dalam proses BAAK pada tahapan ini sebagaian kegiatan dalam proses ini dikelola BAAK, dan dikelompokan berdasasrkan entitas yang ada di bagian penyelenggaraan pendidikan, dapat dilihat pada tabel II dan Sistem Informasi BAAK Gbr 3.

TABEL II

PENYELENGGARAAN PENDIDIKAN BAAK

\begin{tabular}{|c|c|l|}
\hline No & $\begin{array}{c}\text { Kode } \\
\text { Aplikasi }\end{array}$ & \multicolumn{1}{c|}{ Nama Aplikasi } \\
\hline 1 & 1 & Pelaksanaan Akademik \\
\hline 2 & 2 & Pengelolaan Mahasiswa \\
\hline 3 & 3 & Pengelolaan Dosen \\
\hline 4 & 4 & Perwalian \\
\hline 5 & 5 & Jadwal Perkuliahan \\
\hline 6 & 6 & Evaluasi Perkuliahan \\
\hline 7 & 7 & Hasil Studi \\
\hline 8 & 8 & Tugas Akhir \\
\hline 9 & 9 & Pelaporan Akademik \\
\hline
\end{tabular}


TABEL III

Proses PENYELENGGARAAN PENDIDIKAN BAAK

\begin{tabular}{|c|c|c|}
\hline $\begin{array}{c}\text { No } \\
\text { Proses }\end{array}$ & $\begin{array}{c}\text { Nama Sub } \\
\text { Proses }\end{array}$ & Aktivitas Detail \\
\hline I. & $\begin{array}{l}\text { Kebijakan } \\
\text { Akademik }\end{array}$ & $\begin{array}{l}\text { Penetapan Kalender Akademik } \\
\text { Penentuan Pengajar dan Ruang } \\
\text { Kuliah Perwalian Akademik } \\
\text { Pengelolaan Rencana Studi } \\
\text { Perwalian) Perubahan Rencana } \\
\text { Studi (Perwalian) Administrasi } \\
\text { Cuti Akademik }\end{array}$ \\
\hline II. & $\begin{array}{l}\text { Kegiatan } \\
\text { Pembelajaran }\end{array}$ & $\begin{array}{l}\text { Pelaksanaan, Pengawasan dan } \\
\text { Evaluasi PBM Pengelolaan Data } \\
\text { Mahasiswa Pengelolaan Data } \\
\text { dosen Pembentukan Panitia Ujian } \\
\text { Pencetakan Transkrip Akademik } \\
\text { Pelaporan Akademik Pelaksanaan } \\
\text { Sidang Kerja Praktek }\end{array}$ \\
\hline III. & Skripsi & $\begin{array}{l}\text { Pelaksanaan Seminar Skripsi } \\
\text { Penjadwalan Seminar } \\
\text { Pelaksanaan Sidang skripsi }\end{array}$ \\
\hline
\end{tabular}
Gbr.3.

Berikut ini aplikasi Bagian Administrasi Akademik, pada

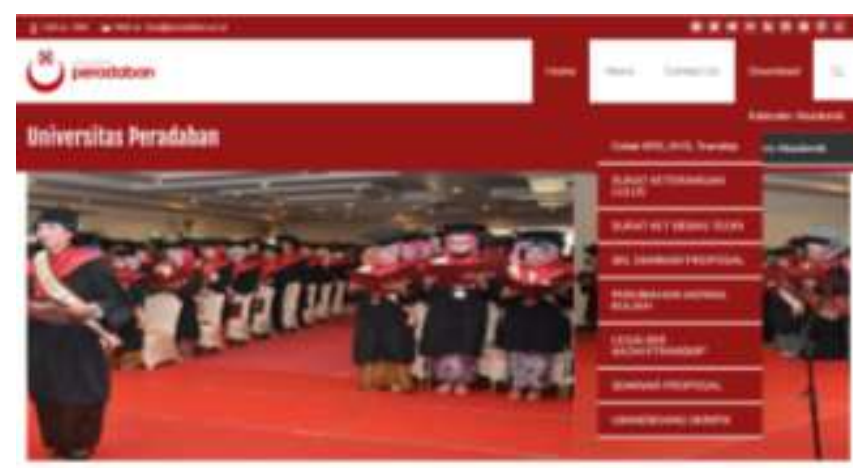

\section{WE ARE BMA AKADEMIK}

Gbr 3. Interface SIM BAAK

\section{3) Masa Akhir Studi}

Masa akhair studi merupakan tahap akhir dari mahasiswa ketika sudah menyelesaikan semua aktifitas yang ada di Universitas Peradaban. Hasil pengelompokan aktifitas-aktifitas dari proses pelepasan mahasiswa, dapat dilihat pada tabel IV.

TABEL IV

MASA AKHIR STUDI MAHASISWA

\begin{tabular}{|c|l|l|}
\hline $\begin{array}{c}\text { No } \\
\text { Proses }\end{array}$ & $\begin{array}{c}\text { Nama } \\
\text { Sub } \\
\text { Proses }\end{array}$ & \multicolumn{2}{|c|}{ Aktivitas Detail } \\
\hline I. & Pelepasan & Perencanaan Wisuda Pembentukan \\
& Mahasiswa & Panitia Wisuda \\
& & Pembuatan ljazah dan Transkrip \\
& & Nilai Pelaksanaan Wisuda \\
& & Pelaporan Evaluasi Kegiatan \\
& & Wisuda Out \\
\hline II. & Penetapan & Penetapan Mahasiswa Drop Out \\
& Status & Penetapan Pengunduran Diri \\
& Mahasiswa & Mahasiswa \\
\hline
\end{tabular}

\section{4) Proses Alumni dan Karir}

Pada Proses ini berisi tentang pengelolaan data alumni yang ada di Universitas Peradaban, yang terdiri dari pendataan para alumni, pendataan tempat bekerja, dan lowongan kerja yang disediakan. Berikut aktifitas-aktifitas dari proses alumni dan karir dapat dilihat pada tabel V.

TABEL V

PROSES ALUMNI DAN KARIR

\begin{tabular}{|c|c|c|}
\hline $\begin{array}{c}\text { No } \\
\text { Proses }\end{array}$ & $\begin{array}{c}\text { Nama Sub } \\
\text { Proses }\end{array}$ & Aktivitas \\
\hline A. & $\begin{array}{l}\text { Pendataan } \\
\text { Alumni }\end{array}$ & $\begin{array}{l}\text { Pembentukan Komite Alumni } \\
\text { Pencatatan Biodata Alumni } \\
\text { Penandaan Lokasi dan Jabatan } \\
\text { Kerja Alumni }\end{array}$ \\
\hline B. & Informasi karir & $\begin{array}{lr}\text { Pengelolaan Data Lowongan } \\
\text { Kerja Masuk } & \text { Pemasangan } \\
\text { Pengumuman } & \text { Lowongan } \\
\text { Kerja } & \end{array}$ \\
\hline
\end{tabular}

D.

\section{Architecture Sistem Informasi}

Tahapan enterprise architecture membagi menjadi 2 tahapan yaitu Pemodelan Arsiterktur database dan Pemodelan Arsitektur teknologi informasi dan komunikasi. Implementasi tidak selalu terpaku pada arsitektur data terlebih dahulu selanjutnya arsitektur aplikasi, akan tetapi bisa mendahulukan arsitektur aplikasi dan dilanjutkan dengan arsitektur data.

\section{1) Model Arsitektur Data}

Dalam tahapan ini mengidentifikasi semua proses utama yang mendukung dalam kegiatan operasional di Universitas Peradaban, berikunya melakukan identifikasi dan pengklasteran data yang dibuat dan digunakan dalam proses tersebut. database adalah sebuah kategori tentang data yang terkait secara logis yang penting untuk mendukung proses bisnis di suatu organisasi. Pendefinisian arsitektur data pada tahapan ini dibuatkan dengan mengidentfikasi calon kandidat class. calon class data yang diidentifikasi haruslah dapat menentukan hal-hal sebagai berikut:

etepatan dalam mendukung ketersediaan data untuk mendukung kegiatan operasional sistem informasi akademik di Universitas Peradaban;

- Penyebaran data yang ada di setiap unit harus saling berkaitan untuk mendukung terintegrasinya database;

- Ketersediaan data pokok yang harus ada di Universitas Peradaban harus teridentifikasi dengan jelas.

\section{2) Entititas Data}

Entitas data yang tersedia dapat dilihat pada tabel VI.

TABEL VI.

ENTERPRISE ARSITEKTUR ENTITY

\begin{tabular}{|c|l|c|l|}
\hline No & $\begin{array}{l}\text { Entitas } \\
\text { Kandidat }\end{array}$ & No & $\begin{array}{c}\text { Entitas } \\
\text { Kandidat }\end{array}$ \\
\hline 1 & Login & 24 & Mata_Kuliah \\
\hline 2 & PMB & 25 & Jadwal_Kuliah \\
\hline
\end{tabular}




\begin{tabular}{|c|c|c|c|}
\hline 3 & Promosi & 26 & Nilai \\
\hline 4 & Jadwal & 27 & Perwalian \\
\hline 5 & Mahasiswa & 28 & Jadwal_Ujian \\
\hline 6 & Asal_Sekolah & 29 & Jadwal_lab \\
\hline 7 & Pembayaran & 30 & Transkrip \\
\hline 8 & Jadwal_Tes & 31 & Absensi_E-Learning \\
\hline 9 & Soal_ujian & 32 & $\begin{array}{l}\text { Daftar_Hadir_Mahas } \\
\text { iswa }\end{array}$ \\
\hline 10 & Hasil_Tes & 33 & $\begin{array}{l}\text { Praktik_Kerja_Prakt } \\
\text { ek }\end{array}$ \\
\hline 11 & Registrasi & 34 & Tugas_Akhir \\
\hline 12 & NPM & 35 & Cuti_Akademik \\
\hline 13 & Kalender_Akademik & 36 & Panitia_Wisuda \\
\hline 14 & Kurikulum & 37 & Calon_Wisuda \\
\hline 15 & BAAK & 38 & Mahasiswa_Lulus \\
\hline 16 & Mahasiswa & 39 & Ijazah \\
\hline 17 & Dosen & 40 & Transkrip_Akademik \\
\hline 18 & Dosen_Pembimbing & 41 & $\begin{array}{l}\text { Mhs_Mengundurkan } \\
\text { _Diri }\end{array}$ \\
\hline 19 & Dosen_Wali & 43 & Alumni \\
\hline 20 & Program_Studi & 44 & Lowongan \\
\hline 21 & Ruang_Kuliah & & \\
\hline 22 & Kelas & & \\
\hline 23 & Absen_Dosen & & \\
\hline
\end{tabular}

\section{E. Aplikasi Architecture}

Tahap ini melakukan identifikasi kebutuhan database pokok yang di butuhkan untuk mengatur semua komponen dalam database dan mengatur fungsi pada proses bisnis pokok enterprise di universitas Peradaban. Database yang dibangun harus ada hubungannya dengan proses bisnis yang sudah dianalisa dan sudah dirancang. Berdasarkan pemetaan bisnis proses, sehingga didapat sebuah sistem informasi akademikyang efektif dan efisien sebagai penunjang bisnis proses di Universitas Peradaban, berikut sistem informasi akademik beserta calon database yang dibutuhkan:

\section{1) Database Penerimaan Mahasiswa Baru}

Aplikasi ini dibutuhkan untuk memanajemen informasi mengenai penerimaan mahasiswa baru. Database yang akan menjadi bagian dari sistem informasi penerimaan mahasiswa baru dapat dilihat pada tabel VII.

TABEL VII

SISTEM INFORMASI PENERIMAAN MAHASISWA BARU

\begin{tabular}{|c|c|c|}
\hline No & $\begin{array}{c}\text { Kode } \\
\text { Aplikasi }\end{array}$ & Nama Aplikasi \\
\hline I & 1 & Penerimaan Mahasiswa Baru \\
\hline II & 2 & Tes Penerimaan Mahasiswa baru \\
\hline
\end{tabular}

\section{2) Database Akademik}

Database yang akan dibagun untuk mengelola sistem informasi Akademik. Sistem yang akan dibangun juga menjadi bagian dari sistem informasi akademik, yang dapat dilihat pada Gbr 4.

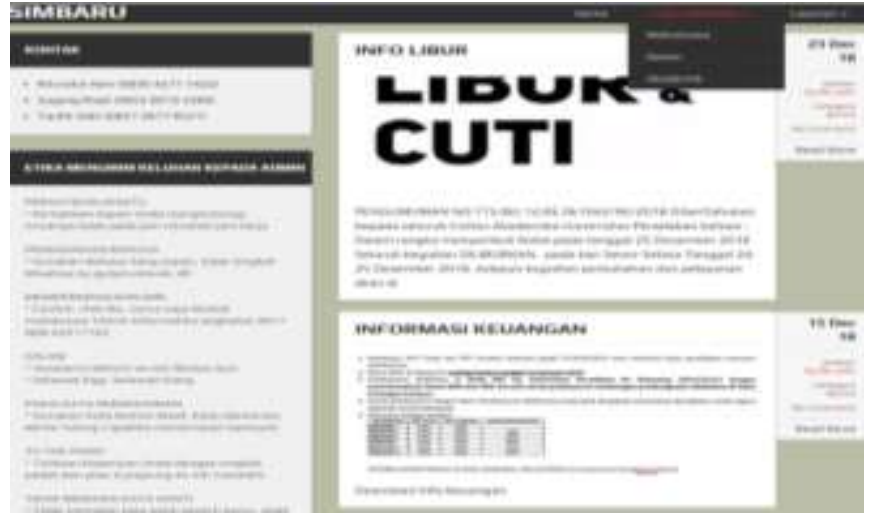

Gbr 4. Sistem Informasi Akademik

\section{3) Aplikasi Layanan Akademik}

Aplikasi ini berkaitan dengan layanan-layanan akademik yang ada adi Universitas Peradaban, Seperti : perpusatakaan, e-learning, repository dan sister. sistem yang akan menjadi bagian dari sistem informasi layanan akademik dapat dilihat pada tabel VIII.

TABEL VIII

SISTEM INFORMASI LAYANAN AKADEMIK

\begin{tabular}{|c|c|l|}
\hline No & $\begin{array}{c}\text { Kode } \\
\text { Aplikasi }\end{array}$ & \multicolumn{1}{|c|}{ Nama Aplikasi } \\
\hline I & 1 & Layanan Perpustakaan \\
\hline II & 2 & Layanan E-Learning \\
\hline III & 3 & Layanan Repository \\
\hline IV & 4 & Layanan Sister \\
\hline
\end{tabular}

\section{E. Architecture Technology}

Model infrastruktur jaringan komputer yang ada di Universitas Peradaban bisa dilihat pada gambar 5, dimana model jaringan yang ada tersebut merupakan gambaran jaringan yang real tetapi bisa berubah suatu saat ketika ada pengembangan jaringan dimana Universitas Peradaban selalu mengembangkan teknologi Jaringan Komputer guna menunjang sistem informasi akademik. Berikut merupakan hasi analisis kondisi Eneterprise Resource Planing teknologi di Peradaban.

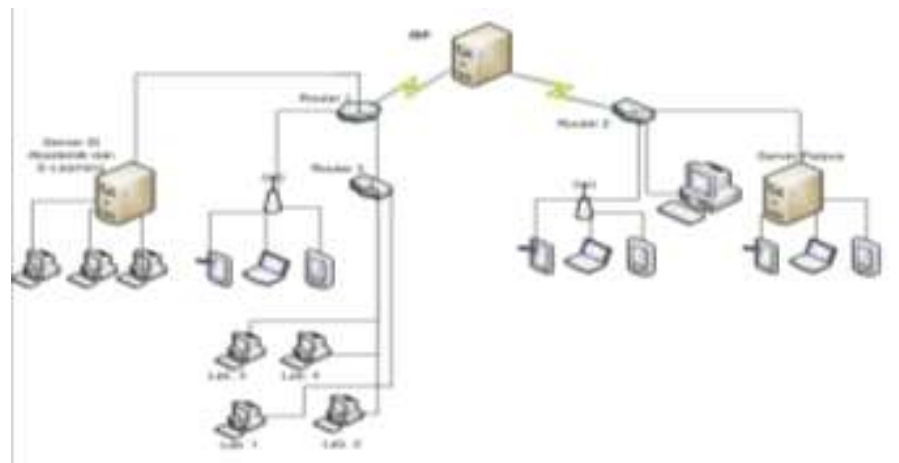

Gbr. 5 Arsitektur jaringan Universitas Peradaban 
Analisa arsitektur teknologi Informasi dan komunikasi yang ada di Universitas Peradaban saat ini sudah mendukung Model Eneterprise Resource Planing. Rekomendasi yang diperlukan pada saat ini adalah update teknologi informasi yang dirasa masih ada terutama penambahan kecepatan server karena jumlah mahasiswa dari tahu ke tahun selalu meningkat, penambahan bandwidth dan penambahan akses point di beberapa tempat, sehingga stabilitas data akan lebih terjaga. Implementasi sistem informasi akademik berbasis website yang bersifat open source adalah untuk memberikan kemudahan dalam hal konfigurasi sistem yang mudah dikases dimana saja dan kapan saja.

Penjelasan teknologi infromasi dan sistem informasi yang di bangun dengan baik dan matang, sehingga menghasilkan kerangka kerja yang handal untuk mendukung visi misi ke depan Universitas Peradaban terutama dalam mengembangkan sistem informasi akademik yang di harapkan.

\begin{tabular}{|l|l|l|}
\hline \multicolumn{2}{|l|}{ Pengelolaan Keuangan } \\
\hline \multicolumn{2}{|l|}{ Pengelolaan Mahasiswa } \\
\hline \multicolumn{2}{|l|}{ Pengelolaan Sumber Daya } \\
\hline \multicolumn{2}{|l|}{ Pengelolaan Perpusatakaan } \\
\hline \multicolumn{2}{|l|}{ Pengelolaan LPPM } \\
\hline $\begin{array}{l}\text { Peneri } \\
\text { maan }\end{array}$ & $\begin{array}{l}\text { Penyel } \\
\text { enggar }\end{array}$ & Layana \\
Mahasi & $\begin{array}{l}\text { Alumni } \\
\text { aan } \\
\text { swa } \\
\text { Baru }\end{array}$ & $\begin{array}{l}\text { Pendidi } \\
\text { kan }\end{array}$ \\
\hline
\end{tabular}

Gbr. 6 Blueprint Eneterprise Resource Planing yang dihasilkan

\section{F. $\quad$ Sollution and Opportunitie}

Model architecture enterprise yang sudah dirancang dengan baik kan menghasilkan sebuah peluang dan solusi yang terbaik. Pada tahapan ini adalah menyelesaikan solusi dengan membuat aplikasi sesuai dengan kebutuhan pengguna beserta solusi teknologi informasi dan komunikasinya. Untuk mendukung proses penerapan teknologi informasi maka dibutuhkan startegi yang terbaik untuk mengurangi beberapa resiko yang mungkin bisa terjadi, di antaranya adalah dengan mempertimbangkan beberapa antara lain:

\section{1) Persoalan Ekonomis (Biaya Implementasi)}

Pada saat menerapkan teknologi informasi dan komunikasi untuk mendukung sistem informasi yang baik faktor ekonomi menjadi sebuah persoalan terutama bagi perguruan tinggi swasta yang baru berdiri karena penyelenggara akan menghitung keuntungan dan kerugian yang akan terjadi apakakh sudah sesuai dengan biaya yang sudah dikeluarkan untuk implemetasinya. Perencanaan Architecture enterprises sistem informasi akademik pada sebuah perguruan, faktor ekonomi sangat diperlukan dalam mengimplemetasi sistem infromasi akademik yang baik dan handal karena akan memerlukan biaya yang cukup besar.
Biaya tersebut dikeluarkan untuk pembelian perangkat keras seperti: server, router, switch hub, akses point, kabel jaringan serta perangkat lainya dan juga penambahan Bandwidth untuk meningkatkan kecepatan akses ke sever. Persoalan ekonomi jangan di lihat dari nilai investasinya saja tetapi juga harus di perhitungkan nilai kemanfaatannya serta keunggulan kompetitif sebuah perguruan tinggi supaya dapat bersaing dengan perguruan tinggi lainnya.

\section{2) Persoalan Sumber Daya Manusia}

Teknologi informasi dan sistem informasi di Universitas Peradaban di tangani bagian Pusat Komputer dan Sistem Informasi (PUKSI) yang terdiri dari ketua, Sekretaris, dan beberapa staf yang ada di bagian puksi dan di bantu beberapa mahasiswa magang dan siswa SMK. Bagian PUKSI memegang peranan sangat penting dalam menunjang keberhasilan implementasi sistem informasi kedepan. Oleh karena itu pelunya penguatan pada sumber daya manusia yang handal dan trampil. Adanya keterlibatan personil PUKSI dalam pengembangan dan implementasi sistem informasi akan memberikan nilai yang sangat positif. Dengan keterlibatan personil yang ada di PUKSI dan BAAK maka perlunya pengembangan sumber daya manusia yang handal terutama bidang teknologi informasi ataupun bidang bisnis prosesnya yang menuntut pengembangan terus menerus demi kemajuan perguruan tinggi.

\section{3) Cara mengatasi pesoalan}

Pada saat melaksanakan pengembangan dan penerapan sistem informasi akademnik antara lain:

- Melakukan ujicoba pada setiap modul yang sudah dibangun;

- Membuat manual book sistem informasi yang sudah dibangun di setiap modul sehingga pengguna bisa mempelajari sistem informasi ini dengan cepat dan mudah;

- Melakukan pelatihan secara berkala baik untuk mahasiswa, dosen dan staf sebagai pengguna aplikasi tersebut;

- Membatasi pengguna tingkat akhir untuk menjaga keamanan sistem informasi;

\section{G. Migration Planning}

Pada tahapan ini adalah membuat sebuah rencana perbaikan atau update sebuah sistem informasi yang sudah ada sebelumnya untuk menerapkan sistem informasi yang baru supaya pada penerapannya sistem tersebut bisa lebih efektif, efisien dan berjalan dengan baik serta lancer. Prosedur awal yang di lakukan adalah dengan membuat tahapan-tahapan penerapan secara sistematis sesuai dengan perencanaan migrasi sistem informasi yang yang dibangun berdasarkan enterprise resource planning sistem informasi akademik di Universitas Peradaban. Enterprise resource planing memberikan gambaran umum bagaimana menerapakan teknologi informasi dak komunikasi untuk mendukung implemetasi sebuah sistem informasi akademik. 


\section{KESIMPULAN}

Hasil dari kesimpulan yang diperoleh dari penelitian ini memberikan kesimpulan, framework TOGAF adalah sebuah framework yang dapat digunakan untuk membangun model enterprise resoucer planning sistem informasi akademik sesuai dengan visi misi organisasi yang terstrukur dan terencana dengan baik sehingga di dapat model blue print sistem infromasi akademik yang handal sesuai dengan yang di harapkan oraganisasi tersebut. Hasil penerapan dan implemetasi enterprise resource planning maka diperoleh empat sistem informasi utama yaitu: pertama sistem informasi penerimaan mahasiswa baru, kedua sistem informasi akademik, ketiga sistem infromasi layanan akademik keempat sistem informasi alumni.

Enterprise resource planning sistem informasi di Universitas Peradaban menghasilkan sebuah proses perbaikan layanan sistem informasi akademik secara menyeluruh dan terintegrasi setiap unit oraganisasi, maka permsalahan yang sering muncul dapat di selesaikan dengan arsitektur sistem informasi yang terintegrasi. Sehingga di dapat infromasi yang cepat, tepat dan akurat serta memberikan kemudahan bagi pengguna.

\section{DAFTAR PUSTAKA}

[1] I. Silanegara, B. Tama, and D. Nurhidayat, "Perencanaan Strategis Teknologi Informasi (Studi Kasus: Politeknik Negeri Jakarta)," $J$. Generic, vol. 6, no. 1, pp. 13-18, 2013.

[2] S. Kasus, R. Soegiri, and Y. Kustiyahningsih, "Perencanaan Arsitektur Enterprise Menggunakan Metode Togaf Adm," Perenc. Arsit. Enterp. Menggunakan Metod. Togaf Adm, pp. 1-8, 2013.

[3] C. R. Mardiansyah, "Analisis Dan Pengembangan Enterprise Arsitektur Menggunakan Framework Togaf Pada Pengadilan Agama Bandung," 2013.

[4] R. Setiawan, "Perancangan Arsitektur Enterprise Untuk Perguruan Tinggi Swasta Menggunakan TOGAF ADM," J. Algoritm. STT Garut, vol. 12, no. 1, p. 14, 2015.

[5] R. Yunis and K. Surendro, "Perancangan Model Enterprise Architecture Dengan Togaf Architecture Development Method," Semin. Nas. Apl. Teknol. Inf., vol. 2009, no. Snati, pp. 25-31, 2009.

[6] S. Rahayu et al., "PERECANAAN ARSITEKTUR ENTERPRISE MENGGUNAKAN FRAMEWORK TOGAF," J. STT-Garut All Right Reserv., vol. 12, pp. 1-8, 2015.

[7] Pratiwindya and R. Akbar, "Implementasi Enterprise Resource Planning (Erp) Pada Sistem Pembelian, Persediaan, Penjualan Dan Customer Relationship Management (Crm) (Studi Kasus : Jaya Utama Motor)," Semin. Nas. Sains dan Teknol. Fak. Tek. Univ. Muhammadiyah Jakarta, vol. 8, no. November, 2016.

[8] S. Wibisono, "Enterprise Resource Planning (ERP) Solusi Sistem Informasi Terintegrasi," J. Teknol. Inf. Din., vol. X, no. 3, pp. 150$159,2008$.

[9] A. Suryadi, "Strategi Perencanaan Dan Penerapan Teknologi Informasi Menggunakan Kerangka TOGAF Versi 9: Studi Kasus Smkn Xyz," Fakt. Exacta, vol. 8, no. 4, pp. 392-399, 2015. 